Journal of Education and Future year: 2021 , issue: $19,49-60$
Nesibe Aydın JEF

\title{
Using Cartoon Discussions for Vocabulary Acquisition in English Language Teaching
}

\begin{tabular}{ccc}
\hline Article Type & Received Date & Accepted Date \\
Research & 6.12 .2019 & 8.11 .2020 \\
\hline
\end{tabular}

Mary Jane M. Özkurkudis*

\author{
Nilay T. Bümen**
}

\begin{abstract}
Action research was carried out in the preparatory program of a foundation university to examine the effectiveness of cartoon discussions in vocabulary acquisition. Students were shown cartoon videos based on the theme of the textbook unit and were asked to answer the guiding questions including the target vocabulary implicitly or explicitly. Students were divided into randomly selected groups and were asked to complete a task using the vocabulary acquired through the learning management system. The students $(n=19)$ were given a pre-and post-test with words that they were supposed to learn during the eight-week process. The tests were assessed by three different teachers (the W-coefficient was found as .944 for inter-rater reliability) using a pre-prepared rubric by the researchers. To evaluate students' perceptions, at the end of the process, students were given a questionnaire. Findings revealed that the post-test results of the students, who acquired vocabulary through cartoon discussion and practiced collaboratively through the learning management system, were significantly higher compared to their pre-test results. Students expressed positive views concerning this method in the questionnaire applied. Acquisition of vocabulary through cartoon discussions was found effective and was well-received by students.
\end{abstract}

Keywords: Vocabulary acquisition, computer-assisted language learning, computer-supported collaborative learning, English language teaching.

\footnotetext{
Corresponding Author: Lecturer, Izmir University of Economics, School of Foreign Languages, Izmir, Turkey. E-mail: mary.ozkurkudis@ieu.edu.tr, https://orcid.org/0000-0003-3663-936X

Prof. Dr., Ege University, Faculty of Education, Department of Educational Sciences, Izmir, Turkey. E-mail: nilay.bumen@ege.edu.tr, https://orcid.org/0000-0003-1891-6589
} 


\title{
İngilizce Dil Eğitiminde Kelime Edinimi için Çizgi Film Tartışmalarının Kullanılması
}

\begin{tabular}{ccc}
\hline Makale Türü & Başvuru Tarihi & Kabul Tarihi \\
Araştırma & 6.12 .2019 & 8.11 .2020 \\
\hline
\end{tabular}

\author{
Mary Jane M. Özkurkudis*
}

Nilay T. Bümen**

\begin{abstract}
$\ddot{O} z$
Bir vakıf üniversitesinin İngilizce hazırlık okulunda kelime edinimi için çizgi film tartışmalarının kullanımı üzerine bir eylem araştırması yürütülmüştür. Öğrencilere ders kitaplarında işlenen temaya dayalı çizgi filmler izletilmiş ve öğrencilerin hedef kelimeleri açık veya örtük bir şekilde içeren yönlendirici soruları cevaplandırması istenmiştir. Öğrenciler rastgele seçilmiş gruplara ayrılmış ve öğrenme yönetim sistemi üzerinden edindikleri kelimeleri kullanarak bir çalışma yapmaları istenmiştir. Sürecin başında ve sonunda uygulanan testte, öğrencilerden $(n=19)$ sekiz haftalık süreç içerisinde öğrendikleri kelimeleri içeren soruları cevaplamaları istenmiştir. Yanıtlar üç farklı öğretmen tarafından önceden hazırlanan bir derecelendirilmiş puanlama anahtarı kullanılarak değerlendirilmiştir (puanlayıcılar arası güvenirlik W-katsayısı .944 olarak hesaplanmıştır). Görüşlerini almak üzere süreç sonunda öğrencilere anket uygulanmıştır. Bulgular, kelimeleri çizgi film tartışmaları ile öğrenen ve işbirlikli bir şekilde öğrenme yönetim sistemi üzerinden verilen bir alıştırmayla pekiştiren öğrencilerin sontest sonuçlarının önteste kıyasla anlamlı olarak yüksek olduğunu göstermektedir. Öğrenciler uygulanan ankette bu yöntem hakkında olumlu görüşler bildirmiştir. Kelime edinimi için çizgi film tartışmalarının kullanılması etkili bulunmuş ve öğrenciler tarafından olumlu karşılanmıştır.
\end{abstract}

Anahtar Sözcükler: Kelime edinimi, bilgisayar destekli dil öğrenimi, bilgisayar destekli işbirliğine dayalı öğrenme, İngilizce dil eğitimi.

\footnotetext{
* Sorumlu Yazar: Öğretim Görevlisi, İzmir Ekonomi Üniversitesi Yabancı Diller Yüksekokulu, İzmir, Türkiye. E-posta: mary.ozkurkudis@ieu.edu.tr, https://orcid.org/0000-0003-3663-936X

** Prof. Dr., Ege Üniversitesi Eğitim Fakültesi Eğitim Bilimleri Bölümü, İzmir, Türkiye. E-posta: nilay.bumen@ege.edu.tr, https://orcid.org/0000-00003-1891-6589
} 


\section{Introduction}

Vocabulary acquisition and retention are the touchstones of teaching and learning a foreign language. Without vocabulary knowledge, it is impossible to efficiently and effectively use the target language. This means, there is a very low possibility of understanding and production to be competent in all four skills namely, reading, writing, listening, and speaking vocabulary is needed.

When it comes to teaching vocabulary, questions always arise about which words to teach, how to identify, and how to teach these, which aids to use, how to increase awareness among students, how to enhance vocabulary retention and how to test the amount of learning (Allen, 1983, p.6). According to McBain (2011), vocabulary can be acquired in various methods; lexical approach, theme-based, lexical phrase method, the grammar-translation method, the audio-lingual method, and the communicative language method. This shows there is not only one effective way to teach vocabulary. When learning vocabulary students need to use their metacognitive skills and learn to understand when and where to use a vocabulary item. Thus, the new word should be taught in a way that students can integrate it into other skills. This should be in a context so that students can retain it (Ubaque \& Pinilla, 2018). One significant point in teaching vocabulary is the choice of items to be taught. Students should be exposed to words based on their level, and the high-frequency words should be firstly presented (An1l, 2011). Many techniques and strategies have been used to teach vocabulary to students of English. Among these techniques are the use of games (Yip \& Kwan, 2006; An1l, 2011;; Bakhsh, 2016; Ebrahimzadeh, 2017; Karaaslan, Kılıç, Yalçın \& Güllü, 2018, Cardoso, Rueb \& Grimshaw, 2017), humourous texts (Zabidin 2015), caricatures (Güven \& Bekdaş, 2018) vocabulary cards (Wilkinson, 2017), the use of drama (Kalogirou, Beauchamp \& Whyte, 2019), visual aids such as videos (Arıkan \& Taraf, 2010; Prosic-Santovac, 2017; Kim \& Gilman, 2018), collaborative learning (Dobao, 2014; Mozaffari, 2017, Mayo \& Zeitler, 2016) and computer-assisted learning such as online teaching or computer-based texts; Averianova, 2015; Khezrlou, Ellis \& Sadeghi, 2017).

As mentioned before, failure in vocabulary acquisition leads to having difficulty in receptive and productive skills (Sa'd \& Rajabi, 2018). Unfortunately, this is a common issue encountered in many institutions. Students find vocabulary acquisition difficult or they perceive it as boring. They have to memorize words and do exercises all the time (Yip \& Kwan, 2006). This is the case with the Turkish educational system, as well. Students prefer to learn a word by memorizing it or by looking it up in the dictionary. However, they tend to forget the word very easily (Kırmızı \& Topçu, 2014). Therefore, as stated previously, various learning strategies need to be applied to raise the awareness of students and to increase their motivation towards vocabulary acquisition. In the institution where the study took place, similar problems were noted in the first researcher's class. Students memorized the words they had learnt during the lessons or checked the "Turkish" meaning of the words with the intention to understand but not to learn. As the words were not learnt in context, they were soon forgotten.

With the enhancements in technology, the emphasis on the use of computers and learning management systems in education has grown, therefore, the use of visual aids is more common now. As visual aids hold an important place in learning (An1l, 2011), and as some studies have been conducted recently on the use of cartoons and videos to teach vocabulary (Arıkan \& Taraf, 2010; Kim \& Gilman, 2018; Prosic-Santovac, 2017;), cartoons were used to teach and recycle vocabulary in this study. However, the studies carried out on the use of cartoons in vocabulary acquisition mainly focused on young learners (i.e. Arıkan \& Taraf, 2010; Prosic-Santovac, 2017), they lasted two to four weeks, they covered only one topic and they merely gave the word and its definition. In fact, interpersonal skills, positive attitudes towards group work and social interactions are strengthened during the collaborative learning process, where social interdependence and interaction take place (Lin, Hsiao, Tseng \& Chan, 2014). Therefore, using cartoon discussions to increase the motivation in learning vocabulary can combine the positive impacts of group work with the interest the cartoons arise. Thus, this study was conducted at university level, the topics of the cartoons changed based on the topics of the coursebook the students were using, and the words taught were implicitly given by the help of guiding questions through discussions. Students were asked to complete a collaborative task on the learning management system at the end of each cartoon. The study focused on the following research questions: 
1. Will there be any differences in students' achievement when new lexis is taught through cartoon discussions?

2. According to the students,

a) are cartoon discussions effective in vocabulary acquisition?

b) do computer-assisted group assignments foster the use of newly acquired vocabulary items through cartoon discussions?

c) what are students' perceptions of learning vocabulary through cartoon discussions and group assignments?

Based on the results of the study, this method, if found effective, can be implemented into other courses and institutions. As mentioned before, to be able to communicate effectively in a foreign language, one needs to have high competence in vocabulary. Vocabulary acquisition requires time and effort. However, when learners are involved in the process and when teaching and learning take place within the interests of the learners, the level of vocabulary acquisition increases. As students are expected to use the vocabulary learnt through cartoon discussions in their post-tasks, they are given a chance to recycle the words they have learnt. This study shows that no matter at what age students are, cartoons still arise students' interest and help them learn. Moreover, it reveals the importance of computer-assisted group assignments to recycle vocabulary. It can serve as a model for other higher education institutions that encounter the same problems as this study is carried out at university level, not at primary school or kindergarten level, like other research in literature (Arıkan \& Taraf, 2010; Prosic \& Santovac, 2017) and, as a result; it can fill the gap.

\section{Literature Review}

There are various ways and methods to teach and learn vocabulary. Some of these are explanation and repetition (Sa'd \& Rajabi, 2018), games (An1l, 2011), vocabulary cards (Wikinson, 2017), and drama (Kalogirou, et. al, 2019). Research has been carried out to reveal the effectiveness of these techniques and to receive students' and teachers' perceptions. Results showed that implementing all these strategies and techniques improved students' vocabulary skills and affected their performance positively.

A commonly used type of collaborative learning, computer-supported collaborative learning, 'aims to explore how computers can be used to create an effective learning environment that supports collaboration in small groups' (Lin, Hsiao, Tseng \& Chan, 2014, p. 163). Based on this method, studies were conducted to find out technology use in teaching vocabulary and its effects on collaborative work (Averianova 2015; Karaaslan, et. al, 2018; Khezrlou, Ellis \& Sadeghi, 2017; Lin, et al., 2014; Yip \& Kwan, 2006). Findings revealed that the participants that learned individually showed higher performance compared to the ones that worked in groups. For instance, Yip and Kwan (2006) found that learners playing online vocabulary games with groups tend to learn better and could retain the learnt vocabulary for a longer period and retrieve more words than those who simply attended face-to-face lessons. It was noted that teachers needed more training on this method; however, students' attitude was positive as their vocabulary knowledge and retention level increased.

Research has also been carried out to show the effects of multimedia components, video games, interactive games and humorous material on vocabulary acquisition and retention (; Cardoso et. al, 2017; Ebrahimzadeh, 2017; Güven \& Bekdaş, 2018; Kim \& Gilman, 2008; Prosic-Santovac, 2017; Zabidin, 2015). Results revealed that participants learned better when they were exposed to visuals, they were more successful, and achievement was higher. In the context of a game, vocabulary can be acquired without pressure and variety in game formats including text, audio, video, animation or interactivity, and features that encourage challenge, imagination, curiosity, control, competitiveness or recognition are successful in attracting and helping learners stay focused (Karaaslan et al., 2018). Besides, unlike other audiovisual content, using cartoon films as a source of authentic language helps teachers to engage students, attract their attention, create a non-threatening environment for presenting knowledge, and has the potential to improve critical thinking and discussion skills (Abuzahra, Farrah \& Zalloum, 2016). Nasab and Motlagh (2017) also found that participants in the experimental group with subtitled cartoons performed significantly better and learned more vocabulary compared to the control group. 
Based on research conducted and the findings, students are more motivated and acquire new vocabulary items easily when cartoons, caricatures and videos are used. Moreover, the use of visuals and technology enhances vocabulary retention. Although in previous research findings regarding the contributions of cartoon videos to learning English as a foreign language and mainly to vocabulary acquisition were identified, these studies have been carried out with K-12 or younger students. Moreover, even though these studies focused on vocabulary acquisition through cartoons, video games or online activities, none of them included discussions performed collaboratively. This study, different from the other studies involving the use of cartoons (Arıkan \& Taraf, 2010; Prosic \& Santovac, 2017), was conducted at university level with a variety of contextualized cartoons followed by discussions and online collaborative tasks. The study may assist lecturers seeking different techniques when teaching vocabulary.

\section{Method}

This study adopts the action research design. Action research is carried out to understand how efficiently educational practices take place and how problems can be addressed in such practices (Johnson, 2015). This research model was applied since the first researcher of this study implemented all the process in her classroom. During the research a pre-test and post-test were developed by the researchers, and a questionnaire was given to the participants to collect data. The study was conducted in the spring term of 2018 .

\section{Participants}

The participants consisted of 19 preparatory school students whose ages ranged from 17 to 19 . Based on their success in the previous levels and the results of the level exit exam, the level of English of these students was determined as upper-intermediate (B2). The students followed a modular system which lasted eight weeks, and they took integrated skills, reading and writing, and listening and speaking courses. They were exposed to vocabulary in all lessons.

\section{Action Plan}

Initially, students were given a pre-test including the vocabulary that would be taught during the eight-week process. The pre-test, prepared with the help of curriculum and testing experts, consisted of 35 questions categorized into six different question types; (1) writing the definition, (2) reading the definition and identifying the word, (3) matching the words to their definitions, (4) filling in the blanks, (5) finding the word with a different meaning, and (6) matching the pictures with the words. Students were exposed to these words for the first time as the vocabulary selected was from the B2 level vocabulary corpus and the students were at A2 level. Only 5-6 most frequently words were identified based on the units of the coursebook. The cartoons were chosen based on the themes of the units in the coursebook and the identified vocabulary items.

To overcome monotony, students were shown a variety of cartoons, and animations or short animated movies. The duration of the cartoons ranged from 2 minutes to 10 minutes not to cause loss of interest. An action plan (see Table 1) and lesson procedures (see Table 2) were prepared. Students were given a task consisting of guiding questions before watching the cartoons, were asked to take notes while watching, and later to share their ideas with their peers. The questions included target vocabulary that students would understand from context or from clues in the questions. Table 1. 


\section{Table 1}

Action plan

\begin{tabular}{|c|c|c|c|}
\hline Week & Theme & Cartoon/Animation & Vocabulary Items \\
\hline 1 & Pre-Test & "Globalization" & authentic, \\
\hline & Globalization & https://www.youtube.com/watch?v=JJ0nFD19eT8\&t=59s & $\begin{array}{l}\text { consumption, labour, } \\
\text { situated, poverty }\end{array}$ \\
\hline 2 & Education & $\begin{array}{l}\text { "You're a good man Charlie Brown" } \\
\text { https://www.youtube.com/watch?v=VSgouAQQgJI }\end{array}$ & $\begin{array}{l}\text { challenging, range, } \\
\text { credible, significant, } \\
\text { core }\end{array}$ \\
\hline 3 & Medicine & $\begin{array}{l}\text { "Scarlett" } \\
\text { https://www.youtube.com/watch?v=JOWiPx5VRUU\&t=5s }\end{array}$ & $\begin{array}{l}\text { remedy, adequate, } \\
\text { precise, debate, burden }\end{array}$ \\
\hline 4 & Risk & $\begin{array}{l}\text { "Kids Safety" } \\
\text { https://www.youtube.com/watch?v=u05eUAE2C1g\&t=365s }\end{array}$ & $\begin{array}{l}\text { compulsory, reduction, } \\
\text { liable, regulation, } \\
\text { contingency }\end{array}$ \\
\hline 5 & Environment & $\begin{array}{l}\text { "A day in Pompeii" } \\
\text { https://www.youtube.com/watch?v=N-upaByYclM }\end{array}$ & $\begin{array}{l}\text { mitigation, } \\
\text { construction, hamper, } \\
\text { casualty, ancient, } \\
\text { severe, relocate, ban }\end{array}$ \\
\hline 6 & Energy & $\begin{array}{l}\text { "Mr. Bean-Electricity" } \\
\text { https://www.youtube.com/watch?v=2CnE-04eVM4\&t=235s }\end{array}$ & $\begin{array}{l}\text { source, generate, } \\
\text { urgent, diminish, } \\
\text { turbine }\end{array}$ \\
\hline 7 & Aging & $\begin{array}{l}\text { "Forever young" } \\
\text { https://www.youtube.com/watch?v=Z30ZP0AoAdU }\end{array}$ & $\begin{array}{l}\text { rely on, elderly, } \\
\text { impact, decline, } \\
\text { fragile, consult }\end{array}$ \\
\hline 8 & $\begin{array}{l}\text { Post-Test \& } \\
\text { Survey }\end{array}$ & ---- & ----- \\
\hline
\end{tabular}

Table 2

Lesson procedures

\begin{tabular}{|c|c|c|}
\hline Stages & Interaction & Type of work \\
\hline $\begin{array}{l}\text { 1. Students watch the cartoon and answer the } \\
\text { guiding questions. }\end{array}$ & $\begin{array}{l}* \mathrm{Ss} \rightarrow \text { cartoon } \\
\mathrm{Ss} \rightarrow \text { task }\end{array}$ & Individual work \\
\hline 2. Students compare and discuss their answers. & $\mathrm{S} \leftrightarrow \mathrm{S}$ & Pair-work \\
\hline 3. Students share their ideas about the questions in English. & $\mathrm{Ss} \leftrightarrow \mathrm{Ss}$ & le-class \\
\hline $\begin{array}{l}\text { At this stage, target vocabulary is presented using the guided discovery } \\
\text { method with the help of the guiding questions that include the target } \\
\text { word. }\end{array}$ & $\begin{array}{l}\mathrm{S} \leftrightarrow \mathrm{S} \\
\mathrm{Ss} \leftrightarrow \mathrm{T} \\
\mathrm{S} \leftrightarrow \mathrm{T}\end{array}$ & discussion \\
\hline $\begin{array}{l}\text { 4. Students are placed into groups on the learning management system } \\
\text { and are assigned a task where they need to use the vocabulary they have }\end{array}$ & $\mathrm{Ss} \leftrightarrow \mathrm{Ss}$ & $\begin{array}{l}\text { Collaborative group } \\
\text { work }\end{array}$ \\
\hline
\end{tabular}
learnt.

*Ss (students), S (student), T (teacher)

At the end of each week, students were given five days to complete a collaborative task (see Table 3) related to the vocabulary acquired through cartoon discussions and were asked to complete the task through the learning management system using the vocabulary they have learnt. Each week they were randomly placed into a group. They worked in groups of four-five to write a short paragraph as an answer to the task by using as many of the new words they had learnt. As the students completed the tasks on the learning management system even if they were absent in class, they could cooperate with their friends through the system. Students were given feedback through the learning management system. 
Table 3

Questions for collaborative group work

Weeks Questions for collaborative group work

Week 1 Based on the class discussions about the animation you watched, what can you say about the negative effects of globalization?

Week 2 Having watched the cartoon "You're a good man Charlie Brown", write your opinion about the three characters: Lucy, Linus and Charlie Brown.

Week 3 You are a teacher in Scarlett's school, and you know that the little boy has a serious illness. What would you do to give him some hope? How would you help him?

Week 4 If you were the teacher of the Kools family in the safety education course they are taking, what would you teach them? What would be your suggestions?

Week 5 You are a survivor of the volcano eruption in Pompeii. Can you describe those moments?

Week 6 You are Mrs. Wicket and you are describing what has happened to the police. Tell us your side of the story.

Week 7 You are the psychologist of the old lady in the animation. How would you help her?

After the eight-week process, students were given the same vocabulary test as post-test and the difference in their grades was measured. A questionnaire prepared by the researchers was also applied to get students' perceptions concerning the process.

\section{Instruments}

Data was collected through a vocabulary test and a questionnaire prepared by the researchers. Students were asked to complete a vocabulary quiz that consisted of 35 questions with an overall score of 5 as pre-test and post-test. The quiz was assessed by three graders using a rubric (see Appendix A). The quiz questions and the rubric were evaluated by three testing unit members in terms of validity and reliability, and one specialist's views were also taken.

Apart from the rubric, a questionnaire with 22 questions was used to collect feedback on the effectiveness of the cartoon discussions in terms of acquisition, computer-assisted group assignments and student perceptions. The survey questions were formed based on the research questions and subquestions, and a specialist's view was taken during the preparation process. The scores of the survey ranged from 1 to 5 (1-strongly disagree and 5-strongly agree). To check validity, the survey was evaluated and answered by two instructors and a curriculum developer.

\section{Data Analysis}

The vocabulary quizzes were assessed by three raters using a rubric. To determine consistency among the three raters, Kendall's coefficient of concordance was analyzed, and in the pre-test Kendall's W was noted as .944 and, in the post-test, it was .963. Therefore, grading was found to be consistent.

After checking whether the normal distribution assumptions were met, a t-test for dependent groups was performed. In order to quantify the difference between the results of the students, the effect size was analyzed. Frequency analyses and descriptive analyses were conducted to analyze quantitative data from questionnaires using IBM SPSS 21.

\section{Results}

RQ1: "Will there be any differences in students' achievement when new lexis is taught through cartoon discussions?"

Results of the $\mathrm{t}$ test for dependent groups based on the pre-test and post-test scores show that the action plan elicited a statistically significant difference in vocabulary acquisition $(t=-6.60, p<.001)$. The results of the tests are given in Table 4. 
Table 4

Results of t test for dependent groups $(n=19)$

\begin{tabular}{llll}
\hline & $\mathrm{M}$ & $\mathrm{SD}$ & $t$-value \\
\hline Pre-test & 1.63 & 0.68 & $-6.60^{*}$ \\
Post-test & 2.78 & 0.71 & \\
\hline
\end{tabular}

$* p<.001$

According to Table 4, the mean score of the pre-test was 1.63 whereas, it was 2.78 for the posttest. The calculated $t$-value was -6.60 . As $p$ was $<.001$, it could be said that there was a significant difference between the two tests $(\mathrm{ES}=1.65)$. The calculated effect size (1.65) value, according to the classification of Cohen, Manion and Morrison (2007) showed a strong effect [Cohen, Manion and Morrison, (2007) identified the effect size levels as; between 0.0 and 0.2 weak, between 0.21 and 0.50 modest, between 0.51 and 1.00 moderate, 1.00 and above strong effect]. As a result, it can be said that the action plan conducted served its purpose.

RQ2: "According to the students, a) are cartoon discussions effective in vocabulary acquisition? b) do computer-assisted group assignments foster the use of newly acquired vocabulary items through cartoon discussions? c)what are students' perceptions of learning vocabulary through cartoon discussions and group assignments?" To answer these questions, students were given a questionnaire to complete, and the results were analyzed based on the frequency of the answers they gave and based on the findings of a descriptive analysis. The detailed findings are presented in Table 5.

\section{Table 5}

Results of the questionnaire $(n=19)$

\begin{tabular}{|c|c|c|}
\hline QUESTIONS & $\mathbf{M}$ & SD \\
\hline $\begin{array}{l}\text { 1. Learning vocabulary by talking about cartoons is more interesting than learning it } \\
\text { from the book. }\end{array}$ & 4.58 & .61 \\
\hline $\begin{array}{l}\text { Learning vocabulary by watching and discussing the cartoons is better than } \\
\text { learning it just from the teacher. }\end{array}$ & 4.05 & .78 \\
\hline I cannot understand the meaning of new words even if I watch the cartoon. & 2.32 & .82 \\
\hline I can focus more on the vocabulary tasks because watching cartoons is fun. & 4.16 & .83 \\
\hline I like using the coursebook when I learn vocabulary. & 2.63 & 1.11 \\
\hline I want my teacher to give me the definition of the words. & 4.37 & .68 \\
\hline I think I cannot improve my vocabulary by watching cartoons. & 2.21 & 1.27 \\
\hline I prefer learning vocabulary from my teacher, not from the cartoon discussions. & 2.42 & .77 \\
\hline $\begin{array}{l}\text { 9. I think guessing vocabulary is more beneficial than just writing the meaning of } \\
\text { the new words. }\end{array}$ & 3.89 & 1.10 \\
\hline I find watching and talking about cartoons boring. & 1.57 & .61 \\
\hline $\begin{array}{l}\text { Doing group assignments about the vocabulary in cartoons enhances my memory } \\
\text { for vocabulary. }\end{array}$ & 3.95 & 1.22 \\
\hline I do not like doing homework with other students. & 2.79 & 1.47 \\
\hline I can remember the new words easily when I learn them through cartoons. & 3.74 & 1.04 \\
\hline I do not think group assignments help us to remember the new words. & 2.89 & 1.45 \\
\hline Doing vocabulary exercises on my own is more suitable for me. & 3.21 & 1.40 \\
\hline $\begin{array}{l}\text { 16. Practicing vocabulary by doing exercises in the book is more beneficial than } \\
\text { working in groups. }\end{array}$ & 3.00 & 1.33 \\
\hline Learning vocabulary through cartoons did not improve my English at all. & 1.84 & .90 \\
\hline $\begin{array}{l}\text { 18. I can remember the new words easily because I draw a connection between the } \\
\text { word and the cartoon. }\end{array}$ & 4.10 & .94 \\
\hline 19. I do not feel comfortable when doing group assignments. & 2.05 & 1.27 \\
\hline 20. I think I cannot learn vocabulary by watching cartoons. & 1.58 & .61 \\
\hline $\begin{array}{l}\text { 21. When I learn vocabulary items through cartoon discussions, I forget them very } \\
\text { quickly. }\end{array}$ & 2.42 & 1.02 \\
\hline 22. In general, I like learning vocabulary through cartoon discussions. & 4.16 & .90 \\
\hline
\end{tabular}


The items that scored between 4.00-5.00, in an ascending order, were: (a) learning vocabulary by watching and discussing the cartoons is better than learning it just from the teacher; (b) I can remember the new words easily because I draw a connection between the word and the cartoon; (c) I can focus more on the vocabulary tasks because watching cartoons is fun; (d) in general, I like learning vocabulary through cartoon discussions; (e) I want my teacher to give me the definition of the words; (f) learning vocabulary by talking about cartoons is more interesting than learning it from the book. The items that scored below 2.00 were: (a) I find watching and talking about cartoons boring; (b) learning vocabulary through cartoons did not improve my English at all and (c) I think I cannot learn vocabulary by watching cartoons.

In terms of group assignments, to recycle vocabulary learnt through cartoon discussions, students were mainly positive: (a) doing group assignments about the vocabulary in cartoons enhances my memory for vocabulary (3.95); (b) doing vocabulary exercises on my own is more suitable for me (3.21); (c) practicing vocabulary by doing exercises in the book is more beneficial than working in groups (3.00); (d) I do not think group assignments help us to remember the new words (2.89); (e) I do not like doing homework with other students (2.78), and (f) I do not feel comfortable when doing group assignments (2.05).

\section{Discussion, Conclusion and Recommendations}

This study was carried out to evaluate how effective cartoon discussions are on vocabulary acquisition, and how collaborative and computer-assisted learning fosters the use of newly acquired vocabulary items. Students were shown cartoon videos based on the themes of the book they were using, and vocabulary items were elicited either implicitly following the guided discovery method or explicitly. Students were asked to complete a group assignment on the learning management system. The groups were formed randomly. To assess the effectiveness of the method used, a vocabulary test was given as pre-and post-test. Students were asked to complete a questionnaire where they expressed their attitude towards the method applied. Results revealed that students benefited from this method, and there was a significant difference between pre-and post-test results.

As discussed in literature review, reciting, repeating words and using them in context are the most effective strategies for vocabulary acquisition and retention (Sa'd \& Rajabi, 2018). In this study, students were taught vocabulary items through cartoon discussions and were provided with a task where they would use them in context. The findings showed no difference from the above study proving that students learn vocabulary more effectively when given in context.

Studies concerning humorous material, videos, cartoons, and games (Arıkan and Taraf, 2010; Averianova, 2015; Ebrahimzadeh, 2017; Karaaslan, et. al., 2018; Kim \& Gilman, 2008; ProsicSantovac, 2017; Cardoso, et. al, 2018; Yip and Kwan, 2006; Zabidin, 2015) reveal that such methods prove to be more effective in learning and remembering vocabulary. When students were asked whether they found learning words through cartoon discussions more beneficial or not, most responses were positive stating that this method was more fun and that it was easier to learn and remember words in this way. Students thought that watching and talking about cartoons was more interesting compared to learning vocabulary from textbooks, and that learning vocabulary via this method improved their vocabulary skills.

Having watched and discussed the content of the videos, students were asked to work in randomly selected groups and to complete a task via the learning management system. They were encouraged to use the words that they had previously learnt. As stated by both Lin et.al (2014) and Mozaffari (2017) when students are asked to produce a task, it is better to put them in pairs or groups rather than asking them to work individually.

In this study, students were asked to complete their final task in previously assigned groups. They were not expected to work individually. The groups were formed through the learning management system by random selection and consisted of four-five students. Students stated that working collaboratively increased their motivation and that helped them remember the words as they had discussed the task together. This was the case also in the studies carried by Dobao (2015) and Mayo and Zeitler (2017). Therefore, it can be said that group work facilitates vocabulary learning and makes students feel better. 
The findings of the questionnaire were highly satisfactory. Students were asked whether they preferred learning vocabulary through a textbook or cartoons and most of them answered that cartoons helped them acquire vocabulary more easily compared to learning it through textbooks. This is because watching cartoons is fun and the content of the cartoons, as stated in Prosic-Santovac's (2017) research, is more attractive for students in terms of learning.

During the study the majority of the students wanted the teacher to give the definition of the vocabulary item. However, the teacher encouraged the students to understand the meaning of the word from context using guiding questions and did not provide them with a definition. This behavior results from the way students have been trained to learn vocabulary. As stated by Kırmızı and Topçu (2014) students prefer to be spoon-fed, they want to get the definition of the word without spending any effort, as they are mainly exam driven. They usually try to memorize lists of words thinking that they will learn them by heart (Read, 2000).

Students favored collaborative cartoon discussions while performing the tasks given. They thought it helped them learn and remember the new words. They expressed that they felt more comfortable working in groups. Only a few considered working individually more convenient. This may be because of learning style preferences, influence of culture or lack of self-confidence (Flowerdew, 1998) or it may be that they only consider it as a group work but not teamwork where they share responsibilities and help each other (Oakley, Brent, Felder \& Elhajj, 2004).

To conclude, we live in a technological era where everything is carried out through computers and smart devices. Education is one of the fields that accept many technological improvements with the involvement of computers, software and apps, and the demand from the new generation. Therefore, using technology in class proves to be effective. Students learn more effectively and efficiently when they are introduced to a subject through a digital platform. As we all know, it is quite challenging to learn a lot of new words when learning a new language. This can be possible through motivating content such as videos, cartoons, and fun material (AlShajiji, 2015; Arıkan \& Taraf, 2010; Averianova, 2015; Calvo-Ferrer, 2017; Ebrahimzadeh, 2017; Karaaslan et. al., 2018Kim \& Gilman, 2008; Prosic-Santovac, 2017; Cardoso, et. al, 2017; Yip \& Kwan, 2006; Zabidin, 2015). As various research reveals, to enhance retention, assigning students duties and asking them to work collaboratively proves to be effective (Dobao, 2015; Mayo \& Zeitler, 2017).

Vocabulary acquisition through cartoon discussions is effective. However, some limitations should be considered. The study was carried out with a small number of students and it was limited to eight weeks. This did not make it possible to test retention in the further stages of students' learning. However, students were able to remember and use the words they had learnt during the eight weeks. Further suggestions would be to carry out the study in a larger group for a longer period of time and to provide students with the guiding task beforehand to familiarize themselves with the content of the video. After watching the cartoon video, students should be given enough time to brainstorm the guiding questions provided and asked to share ideas in pairs before a whole-class discussion. Moreover, the follow-up tasks assigned should be introduced to the students at the end of the lesson and enough time should be allocated to complete them. To evaluate the long-term effectiveness of this method, further studies can be done to test the level of retention when vocabulary is acquired through this method. The convenience of this method should be evaluated in other institutions and more intense courses. This study can be carried out in other foreign language courses or with students with lower level of English to observe its effectiveness and to evaluate student performance in different levels and fields.

\section{References}

Abuzahra, N., Farrah, M.A. \& Zalloum, S. (2016). Using cartoon in language classroom from a constructivist point of view. Arab World English Journal (AWEJ), 3, 229-245.

Allen, V. F. (1983). Techniques in Teaching Vocabulary. Oxford: Oxford University Press.

Anil, B. (2011). Teaching vocabulary through games- a sanguine step. i-manager's Journal on English Language Teaching, 1(4), 46-50.

Arıkan, A., \& Taraf, H. U. (2010). Contextualizing young learners' English lessons with cartoons: focus on grammar and vocabulary. Procedia Social and Behavioral Sciences 2, 5212-5215. 
Averianova, I. (2015). Vocabulary acquisition in L2: does CALL really help? EUROCALL Conference (pp. 30-35). Padova: Dublin: Research-publishing.net. doi:http://dx.doi.org/10.14705/rpnet.2015.000306

Bakhsh, S. A. (2016). Using games as a tool in teaching vocabulary to young learners. English Language Teaching, 9(7), 120-128.

Cardoso, W., Rueb, A., \& Grimshaw, J. (2017). Can an interactive digital game help French learners improve their pronunciation? EUROCALL, (pp. 67-72). doi:10.14705/rpnet.2017.eurocall2017.691

Cohen, L., Manion, L., \& Morrison, K. (2007). Research Methods in Education. London \& New York: Routledge Falmer.

Cooperstein, S. E., \& Kocevar-Weidinger, E. (2004). Beyond active learning: a constructivist approach to learning. Reference Services Review, 32(2), 141-148. doi:10.1108/00907320410537658

Dobao, A. F. (2014). Vocabulary learning in collaborative tasks: a comparison of pair and small group work. Language Teaching Research, 18(4), 497-520. doi:10.1177/1362168813519730

Ebrahimzadeh, M. (2017). Readers, players, and watchers: EFL students' vocabulary acquisition through digital video games. English Language Teaching, 10(2), 1-18.

Flowerdew, L. (1998). A cultural perspective on group work. ELT Journal, 52(4), 323-329. doi:10.1093/elt/52.4.323

Güven, S., \& Bekdaş, M. (2018). The effect of using caricatures on vocabulary retention in foreign language teaching. International Journal of Eurasia Social Sciences, 9(31), 622-647.

Johnson, A. P. (2015). Eylem araştırması el kitabı [Handbook of action research]. (Y. Uzuner \& M. Ö. Anay, Trans.) Ankara: Anı.

Kalogirou, K., Beauchamp, G., \& Whyte, S. (2019). Vocabulary Acquisition via Drama: Welsh as a second language in the primary school setting. The Language Learning Journal, 47(3), 332-343. doi:10.1080/09571736.2017.1283351

Karaaslan, H., Kılıç, N., Güven-Yalçın, G., \& Güllü, A. (2018). Students' reflections on vocabulary learning through synchronous and asynchronous games and activities. Turkish Online Journal of Distance Education, 19(3), 53-70.

Khezrlou, S., Ellis, R., \& Sadeghi, K. (2017). Effects of computer-assisted glosses on EFL learners' vocabulary acquisition and reading comprehension in three learning conditions. System, 65(C), 104-116. doi: 10.1016/j.system.2017.01.009

Kim, D., \& Gilman, D. A. (2008). Effects of text, audio, and graphic aids in multimedia instruction for vocabulary learning. Educational Technology \& Society, 11(3), 114-126.

Kırmızı, Ö., \& Topçu, N. (2014). Vocabulary Learning Strategies of Turkish EFL Students at Karabük University. Atatürk Üniversitesi Sosyal Bilimler Enstitüsü Dergisi [Ataturk University Journal of Social Sciences Institute], 18(3), 217-232.

Lin, C.-C., Hsiao, H.-S., Tseng, S.-p., \& Chan, H.-j. (2014). Learning English vocabulary collaboratively in a technology-supported classroom. The Turkish Online Journal of Educational Technology, 13(1), 162-173.

Mayo, M. D., \& Zeitler, N. (2017). Lexical language-related episodes in pair and small group work. International Journal of English Studies, 17(1), 61-82. doi:10.6018/ijes/2017/1/255011

McBain, R. (2011, September). Teaching vocabulary to ESL students. Retrieved from ERIC: https://eric.ed.gov/?id=ED523679

Mozaffari, S. H. (2017). Comparing student-selected and teacher-assigned pairs on collaborative writing. Language Teaching Research, 21(4), 496-516. 
Nasab, M. S. B. \& Motlagh, S. F. P (2017). Vocabulary learning promotion through English subtitled cartoons. Communication and Linguistics Studies, 3(1-1), 1-7.

Doi: 10.11648/j.cls.s.2017030101.11

Oakley, B., Felder, R. M., Brent, R., \& Elhajj, I. H. (2004). Turning student groups into effective teams. Journal of Student Centered Learning, 2(1), 9-34.

Prosic-Santovac, D. (2017). Popular video cartoons and associated branded toys in teaching English to very young learners: a case study. Language Teaching Research, 21(5), 568-588.

Read, J. (2000). Assessing Vocabulary. Cambridge: Cambridge University Press.

Sa'd, S. H., \& Rajabi, F. (2018). Teaching and learning vocabulary: what English language learners perceive to be effective and ineffective strategies. C.E.P.S Journal, 8(1), 139-163. doi:10.26529/cepsj.492

Ubaque, D. F., \& Pinilla, F. (2018). Exploring two EFL teachers' narrative events regarding vocabulary teaching and learning. How[online], 25(2), 129-147. doi:https://doi.org/10.19183/how.25.2.400

Wilkinson, D. (2017). EFL Vocabulary acquisition through word cards: student perceptions and strategies. The Electronic Journal for English as a Second Language, 21(3), 1-16.

Yip, F. W., \& Kwan, A. C. (2006). Online vocabulary games as tool for teaching and learning English vocabulary. Educational Media International, 43(3), 233-249.

Zabidin, N. B. (2015). The use of humorous texts in improving ESL learners' vocabulary comprehension and retention. English Language Teaching, 8(9), 104-111.

\section{Appendix A}

\section{Rubric}

\begin{tabular}{|c|c|c|c|c|c|}
\hline $\begin{array}{c}5 \\
\text { Excellent }\end{array}$ & $\begin{array}{c}4 \\
\text { Very good }\end{array}$ & $\begin{array}{c}3 \\
\text { Good }\end{array}$ & $\begin{array}{c}2 \\
\text { Fair }\end{array}$ & $\begin{array}{c}1 \\
\text { Fail }\end{array}$ & $\begin{array}{c}0 \\
\text { No } \\
\text { understanding }\end{array}$ \\
\hline $\begin{array}{l}\text { Student } \\
\text { identified and } \\
\text { knew the } \\
\text { meaning of } \\
\text { more than } 30 \\
\text { words ( } 31- \\
35) \text {. }\end{array}$ & $\begin{array}{l}\text { Student } \\
\text { identified } \\
\text { more than } 25 \\
\text { words }(26- \\
30) .\end{array}$ & $\begin{array}{l}\text { Student } \\
\text { identified } \\
\text { more than } 15 \\
\text { words (16- } \\
25 \text { ). }\end{array}$ & $\begin{array}{l}\text { Student } \\
\text { identified } \\
\text { more than } 5 \\
\text { words }(6-15) \text {. }\end{array}$ & $\begin{array}{l}\text { Student } \\
\text { identified } 5 \\
\text { words or less } \\
(1-5) \text {. }\end{array}$ & $\begin{array}{l}\text { No correct } \\
\text { answers. }\end{array}$ \\
\hline
\end{tabular}

